\title{
Farmers knowledge and perception on maize stem borers and their indigenous control methods in south western region of Cameroon
}

Esther Obi Oben ${ }^{1,2^{*}}$, Nelson Neba Ntonifor ${ }^{2}$, Sevilor Kekeunou ${ }^{1}$ and Martin Nkwa Abbeytakor ${ }^{3}$

\begin{abstract}
Background: Agriculture is a major contributor to the Gross Domestic Product (GDP) of Cameroon, The South West region of Cameroon is known for its potential in the production of major agricultural commodities, but farmers' yields from various speculations are low, dwindling over time due to some major constraints. Maize production is hampered by adverse socio-economic factors, several pests and diseases as well as high rainfall with low solar radiation. Lepidopterous maize stem borers are a major threat to increase maize production. Therefore we hypothesized that the farmers of the South West region: (1) also perceived stem borers as an important pest of maize; (2) they have their own indigenous methods of control; (3) they use chemical pesticides because they have no alternative, but would prefer plant materials if these were standardized.
\end{abstract}

Methods: A semi-structured questionnaire survey was administered in four villages: Maumu, Lower Bokova, Ekona and Bonduma. A total of 151 (male and female) farmers were randomly interviewed to document farmers' perception on stem borers, and their use of indigenous knowledge to manage key pests of maize.

Results: Stem borers were present throughout the maize growing areas in the Fako division and ranked as one of the most important pests of the crop. Most farmers (82.1\%) perceived that stem borers caused significant damage on maize and were responsible for yield reductions in the crop. The increased impact of these pests was due to improper/untimely use of expensive conventional insecticides given the lack of a cheaper alternative method of control. About $50 \%$ of respondent admitted not having any indigenous knowledge of stem borer control, while only $20 \%$ had tried plant products. The most relevant indigenous stem borer control was the use of wood ash. Most (90\%) of the respondent would prefer plant-based insecticides in future because they are safer, cheaper and readily available.

Conclusions: Farmers' knowledge would contribute in understanding the activities of stem borers and use of plant insecticides. Research is therefore needed to standardize the methods of using plant-based products and also identify the active ingredients of these plants to ensure their effectiveness against maize stem borers and other pests.

Keywords: Pest management systems, Farmers' perception, Indigenous knowledge, Plant-based insecticides, Maize stem borers

\footnotetext{
* Correspondence: estherobio1@yahoo.com

${ }^{1}$ Department of Animal Biology and Physiology, Faculty of Science, University

of Yaounde 1, P. O. Box 812, Yaounde, Cameroon

${ }^{2}$ Department of Zoology and Animal Physiology, Faculty of Science,

University of Buea, Buea, Cameroon

Full list of author information is available at the end of the article
} 


\section{Background}

Agriculture is the primary production sector that contributes to the Gross Domestic Product (GDP) of Cameroon [1]. It is also the main source of employment in the country. Maize production is the main source of income for more than three million small-scale farmers in Cameroon. Though the government subsidizes maize production, this support falls far short of farmers' needs due to the myriads of production constraints including persistent pest problems such as stem borers.

Lepidopterous stem borers seriously limit potentially attainable maize yields by infesting the crop throughout its growth stages from seedling to maturity [2]. In Cameroon, maize is grown across all agro-ecological zones, from sea level to the highlands at $2000 \mathrm{~m}$ a.s.l., and the stem borers are present in all these zones. However, the pest densities and plant damage vary greatly between fields [3]. The most important species that reduce maize yield in West and Central Africa are the pink stalk borer, Sesamia calamistis Hampson (Lepidoptera: Noctuidae), the African sugarcane stalk borer, Eldana saccharina Walker (Lepidoptera: Pyralidae) and the maize stalk borer, Busseola fusca Fuller (Lepidoptera: Noctuidae) [4-6]. Yield losses of food grain in areas with severe borer problems vary between 10-70 \% [7-10]. In most of Cameroon, these stem borers are often controlled using conventional insecticides. However, these Synthetic insecticides are unacceptable since they may lead to problems of toxic residues, health and environmental hazards $[9,11]$ when inappropriately used. As stem borers burrow into the stem, they are often protected from contact insecticides [10]. Various methods of cultural control of stem borers in Africa have been reviewed [12-15], these are most relevant and economical to African resource-poor farmers. Though many of these methods are labor intensive, they have little adverse environmental effects and are readily applicable without extra investment in expensive equipment

In Tanzania farmers have greatly relied on indigenous knowledge and/or plant pesticides to meet their daily needs [16]. This knowledge is most relevant to the rural poor and marginalized population. Several indigenous plant based pest management options used for the control of field and storage insect pests have been identified by research in parts of Tanazania [17]. The studies indicated that botanical formulations reduced stem-borer load by more than $55 \%$ and increased maize yield by more than $60 \%$ compared to the control. Over several decades indigenous knowledge practices have been incorporated into scientific knowledge for development and conservation of natural resources [18]. Hegazy et al. [19] and Mugisha-Kamatenesi et al. [20], found that if thoroughly investigated, the current knowledge gained from indigenous plant species may provide more goods and services for local use. In many parts of Africa, derivatives of indigenous plants like Piper guineense and Tephrosia vogelii gained attention because of their insect pest control potential [21, 22]. More so, Jatropha curcas (native to the American tropics, but widely distributed from Senegal to Cameroon) is also widely used for pest control. Entire or powdered fruits of Piper spp. have insecticidal and/or repulsive effects against many pests [23-25].

Despite the enormous potential that has existed for generations, plant based indigenous pest control practices have remained largely unexploited due to limited research intervention and resources committed. However, current interest in reducing environmental contamination and global warming are serving as added impetus for the re-evaluation and intensification of environmentally friendly and cost-effective pest management technologies such as the use of traditional botanical pest control agents [26]. Many studies carried out in parts of Africa found that plant derived ash including those of wood and cocoa pod increased $\mathrm{P}, \mathrm{K}, \mathrm{Ca}, \mathrm{Mg}$ status of soil and $\mathrm{pH}$ and yield of vegetables, rice, millet and maize [27-29]. Farmers' knowledge of various constraints varies qualitatively/quantitatively depending on their interest in the subject, the environment, and its relevance to their lives. Use of indigenous and plant-based insecticides has been greatly neglected in Fako division and this may partly explain why farmers rely solely on synthetic pesticides. In order to improve food security and alleviate poverty in this region, indigenous pest control measures need to be documented and scientifically validated. Their methods of use also need to be standardized in order to popularize these age-old practices.

Therefore, these studies were conducted to investigate farmers' knowledge and perception on maize stem borers and their indigenous control methods in South Western region of Cameroon. We hypothesized that the farmers: (1) perceived stem borers as important pest of maize; (2) they have their own indigenous methods of control and only (3) use chemical pesticides because they have no alternative, but would prefer plant material if these are standardized since they are safer and cheaper.

We therefore sought to know whether or not farmers in the South West Region of Cameroon know about maize stem borers, if they rate them as important pests of maize and how they combat this problem. Farmers were also asked whether or not they used any indigenous methods and/or plant-based products against stem borers, if they could recognize the plants used and how effective these methods were vis-à-vis chemical/synthetic products as well as whether they will prefer to use indigenous or conventional methods to mitigate their maize pest problems in future?

We also sought to know if there were differences in knowledge and practices in controlling maize pest 
problems between men and women as well as among the different villages studied.

\section{Materials and methods Study site}

The survey was conducted in the rainforest agroecological zone of Cameroon. A total of 151 farmers from four villages (Maumu and Ekona for Muyuka subdivision and Lower Bokova, and Bonduma for Buea sub division) in the Fako division of the South West Region were interviewed. Farmers were selected on the bases that each has been involved in maize cultivation for at least one year and were willing to participate in the study. The villages used in the study are in Buea $\left(4^{\circ} 08^{\prime} 036^{\prime \prime} \mathrm{N}, 9^{\circ} 25^{\prime}\right.$ $826 " \mathrm{E} ; 573 \mathrm{~m}$ asl) with rich volcanic rocky soils and temperature ranges of $20-25{ }^{\circ} \mathrm{C}$ and Muyuka $\left(4^{\circ} 150^{\prime}\right.$ $45^{\prime \prime} \mathrm{N}, 9^{\circ} 28^{\prime} 431^{\prime \prime} \mathrm{E} ; 599 \mathrm{~m}$ asl) with sandy soil and high temperatures ranges from $20-28.1{ }^{\circ} \mathrm{C}$, an altitude of $378 \mathrm{~m}$ sub-divisions. The location of these villages in a predominantly agrarian area and gender heterogeneity of the participants was a strong driving force on the farmers' perceptions. Buea is more cosmopolitan, with mountainous rich volcanic soils and favorable climatic conditions for maize cultivation. Muyuka, being warmer, favors the rapid buildup of pest populations. The farming community of the Maumu village in Muyuka is inaccessible due to poor road infrastructures and heavy rains, particularly during the rainy season (June to September). The poor roads prevent proper functioning of markets and lack of agricultural inputs. Most of the farmers being females have no direct contact with extension workers. The main food crops in the region are maize Zea mays, cassava Manihot spp, cocoyam Colocasia esculentum, groundnuts Arachis hypogaea, beans Phaseolus vulgaris, banana/plantains Musa spp, with vegetables and few spices as secondary crops while oil palm Elaeis guineensis, cocoa Theobroma cacao and coffee are the main cash crops.

\section{General characteristics of respondents}

Generally, small-scale (subsistence) farming (86.09 \%) was the primary economic activity of most of the respondents while the remaining, $(9.93 \%)$ practiced farming as a part time job. Within the different villages, $100 \%$ of respondents in Maumu; 40.63 \% in Bonduma; 97.73 \% in Ekona and $97.50 \%$ in Lower Bokova respectively practiced farming as their main occupation. Maize farming experience ranged from 1-50 years. All of the respondent (100 \%) grow food crops, $32.45 \%$ of these also grow cash crops, while $13.33 \%$ kept animals in addition. In all, $76.82 \%$ of the respondents grow their maize in mixed cropping system, $17.22 \%$ in mono cropping while $5.96 \%$ practiced both.

Besides the growing of food crops, most of the farmers in Muyuka subdivision also grew cash crops, especially coffee. Most $(94.04 \%)$ of the farmers plant maize twice a year, while $2.65 \%$ and $3.31 \%$ respectively grow maize once and three times a year. Most $(92.05 \%)$ of the harvested maize is used for household feeding; while $7.95 \%$ is for sale or animal feed. The majority of the respondents (58.94 \%) had completed primary education, $16.56 \%$ had no formal education while $24.51 \%$ had secondary and pre-university education. Within the four villages, $28.13 \%$ in Bonduma, 61.36 \% in Ekona, 62.50 \% in Lower Bokova and $80.00 \%$ in Maumu of the respondents had completed primary education. The study revealed that more farmers in Buea were educated, and involved in business than those in Muyuka. In Muyuka most of the farmers had no formal education; therefore farming was their main source of living (Table 1).

\section{Survey}

A semi-structured questionnaire was used in the survey. A total of 151 farmers $(72.85 \%$ females and $27.15 \%$ males) 35 in Maumu, 40 in Lower Bokova, 44 in Ekona and 32 in Bonduma, were interviewed separately within their farming areas or around their residence. Farmers were selected on the bases that each has been involved in maize cultivation for at least one year and were willing to participate in the study. Interviews were done in English or local language (pidgin) with the assistance of local agricultural extension workers.

The questionnaire sought to know: (a) the kind of indigenous methods and plant products used by farmers

Table 1 Variables showing the significant differences between Muyuka and Buea subdivisions

\begin{tabular}{|c|c|c|c|c|c|c|c|c|c|c|}
\hline & $\begin{array}{l}\text { Harvest } \\
\text { quantity } \\
\text { (KG) }\end{array}$ & $\begin{array}{l}\text { Education } \\
\text { (None) }\end{array}$ & $\begin{array}{l}\text { Occupation } \\
\text { (Business) }\end{array}$ & $\begin{array}{l}\text { Occupation } \\
\text { (Farming) }\end{array}$ & $\begin{array}{l}\text { Crop } \\
\text { grown } \\
\text { (coffee) }\end{array}$ & $\begin{array}{l}\text { Cropping } \\
\text { system } \\
\text { (Both) }\end{array}$ & $\begin{array}{l}\text { Main pest } \\
\text { problem } \\
\text { (Snails) }\end{array}$ & $\begin{array}{l}\text { Type of } \\
\text { pesticide use } \\
\text { (Cypercal 12) }\end{array}$ & $\begin{array}{l}\text { Period of } \\
\text { treatment } \\
\text { (september) }\end{array}$ & $\begin{array}{l}\text { Future } \\
\text { preference } \\
\text { (conventional) }\end{array}$ \\
\hline Buea & $1206 \pm 1840.80$ & $28(7)$ & $88.89(8)$ & $40(52)$ & $30.6(15)$ & $44.4(4)$ & $10(1)$ & $91.7(22)$ & $76.9(20)$ & $25(10)$ \\
\hline Muyuka & $478.99 \pm 1040.49$ & $72(18)$ & $11.11(1)$ & $60(78)$ & $69.4(34)$ & $55.6(5)$ & $90(9)$ & $8.3(2)$ & $23.1(6)$ & $75(30)$ \\
\hline $\begin{array}{l}X^{2} \text { value } \\
\text { or Z- } \\
\text { value* }\end{array}$ & $3.61^{*}$ & 4.8 & 5.44 & 5.2 & 7.4 & 0.11 & 6.4 & 16.7 & 7.5 & 10 \\
\hline$P$-value & 0.0003 & 0.03 & 0.02 & 0.022 & 0.007 & 0.008 & 0.01 & 0.0001 & 0.006 & 0.002 \\
\hline
\end{tabular}

$\mathrm{Z}$ is a Wilcoxon two sample test value 
for maize stem borer control and their main constraints, as well as their knowledge on stem borer problems (b) if they use chemical/synthetic products to control pests, their names, the frequency of use and the constraints linked to their use; (c) whether they had contacts with agricultural extension workers, and their future preference between indigenous and conventional methods in dealing with pests and disease problems in maize fields. Data were also collected on the socio-economic characteristics of respondents.

\section{Statistical analysis}

For each variable, statistical comparison between the two sexes, the two locations and four villages were done based on the procedure of the software SAS ('Statistical Analysis Systems' version 9.1). The frequencies of respondent were also analysed with Chi-square test using PROC PREQ while the Kruskal-Wallis and Wilcoxon two sample tests using the 'Nonparametric One Way' ('NPAR1WAY WILCOXON') procedure were used in the absence of normality to compare the means of quantitative variables. All probabilities were appreciated at the $5 \%$ confidence level.

\section{Results}

\section{Main constraints and major pest problems in maize production}

Participants revealed that the major constraints to increased maize production were: land, labour, finance as well as pest and diseases (Table 2). Pests and diseases were the major constraints $(85.43 \%)$, followed by finances $(55.63 \%)$, land (37.09 \%) and labour (28.48 \%).
There were significant differences between males and females in each village with regard to pests and disease problems. In Maumu, $100 \%$ of the males and $48.15 \%$ of females considered pest and disease as a problem. The same trend was observed in Ekona $(100 \%$ and $93.75 \%)$ and Lower Bokova $(88.10 \%$ and $70.83 \%)$, where males and females respectively considered pest and diseases as their major constraint. On the contrary, in Bonduma more females (94.12\%) than males $(53.33 \%)$ considered pests and diseases as main constraints.

Stem borers $(82.12 \%)$ ranked the highest among the major field pest and disease problems of maize in the study areas. Male and female perceptions were significantly different in all four villages (Table 3). In Maumu, $100 \%$ of female farmers considered stem borers as their major field pest, as against $75 \%$ males. In Bonduma and Ekona, the trend was the same, while in Lower Bokova more males $(100 \%)$ than females $(95.83 \%)$ perceived stem borer as a major threat to maize production. Some of the farmers described that the larvae of the pest bore into the stems and cobs, causing wilting of the plants. Cobs with borer tunnel holes when taken to the market sold at cheaper prices, due to their lower aesthetic values.

Apart from the stem borers, some farmers in Muyuka also considered snails (6.62 \%) as a very important pest, especially during the heavy rains (Table 1$)$. Other pest problems included weevils (16.56\%), white grubs $(11.92 \%)$, birds $(8.61 \%)$ as well as theft $(1.99 \%)$. Due to their meager earnings, most farmers also complained of high prices of pesticides as one of their major constraint.

Table 2 Percentage $( \pm \mathrm{i})$ respondent relative to barriers to increase maize production in Fako Division of South Western Cameroon

\begin{tabular}{|c|c|c|c|c|c|c|}
\hline \multicolumn{6}{|l|}{ All } & \multirow[t]{2}{*}{ Overall } \\
\hline Major constraints & Maumu $(n=35)$ & Lower Bokova $(n=40)$ & Ekona $(n=44)$ & Bonduma $(n=32)$ & $P$-values & \\
\hline Land & $42.9 \pm 7.9 a$ & $22.5 \pm 6.7 b$ & $38.6 \pm 7.8 \mathrm{a}$ & $46.9 \pm 8.0 \mathrm{a}$ & 0.0015 & $37.1 \pm 7.7$ \\
\hline Labour & $22.9 \pm 6.7 b$ & $32.5 \pm 7.5 \mathrm{a}$ & $18.2 \pm 6.1 b$ & $43.8 \pm 7.9 \mathrm{a}$ & $<0.0001$ & $28.5 \pm 7.2$ \\
\hline Finances & $48.6 \pm 8.0 \mathrm{a}$ & $47.5 \pm 7.9 a$ & $63.6 \pm 7.7 a$ & $62.5 \pm 7.7 a$ & 0.1665 & $55.6 \pm 7.9$ \\
\hline Pests and diseases & $97.1 \pm 2.7 a$ & $80.0 \pm 6.4 b$ & $88.6 \pm 5.1 b$ & $75.0 \pm 6.9 b$ & $<0.0001$ & $85.4 \pm 5.6$ \\
\hline \multicolumn{7}{|l|}{ Females } \\
\hline Land & $55.6 \pm 7.9 a$ & $8.3 \pm 4.4 c$ & $35.71 \pm 7.64 b$ & $64.71 \pm 7.62 \mathrm{a}$ & 0.0221 & $39.1 \pm 7.9$ \\
\hline Labour & $18.5 \pm 6.2 c$ & $29.2 \pm 7.3 b$ & $14.29 \pm 5.58 c$ & $47.06 \pm 7.96 a$ & $<0.0001$ & $23.6 \pm 6.8$ \\
\hline Finances & $48.2 \pm 7.9 a$ & $41.7 \pm 7.9 a$ & $61.90 \pm 7.75 a$ & $52.94 \pm 7.96 a$ & 0.5673 & $52.7 \pm 7.9$ \\
\hline Pests and diseases & $48.2 \pm 7.9 b$ & $70.8 \pm 7.3 a$ & $88.10 \pm 5.16 a$ & $94.12 \pm 3.75 a$ & $<0.0001$ & $87.3 \pm 5.3$ \\
\hline \multicolumn{7}{|l|}{ Males } \\
\hline Land & 0 & $43.8 \pm 7.9 b$ & $100 a$ & $26.7 \pm 7.1 \mathrm{c}$ & 0.0191 & $31.7 \pm 7.4$ \\
\hline Labour & $37.50 \pm 7.72 b$ & $37.5 \pm 7.7 b$ & $100 \mathrm{~b}$ & $40 \pm 7.8 b$ & 0.2743 & $41.5 \pm 7.9$ \\
\hline Finances & $50 \pm 7.98 c$ & $56.3 \pm 7.9 c$ & $100 a$ & $73.3 \pm 7.1 b$ & 0.0858 & $63.4 \pm 7.7$ \\
\hline Pests and diseases & $100 a$ & $93.8 \pm 3.9 a$ & $100 a$ & $53.3 \pm 7.9 b$ & $<0.0001$ & $80.5 \pm 6.3$ \\
\hline
\end{tabular}

Zones not sharing a common letter in a row are significantly different at $P=0.05$. ' $\mathrm{p}$-value' is the significance level of Kruskal-Wallis (NA no significance, $P>0.05$ ) 
Table 3 Percentage $( \pm \mathrm{i})$ respondent relative to major pests as barriers to increase maize production in Fako Division of South Western Cameroon

\begin{tabular}{|c|c|c|c|c|c|c|}
\hline \multicolumn{6}{|l|}{ All } & \multirow[t]{2}{*}{ Overall } \\
\hline Major pests & Maumu $(n=35)$ & Lower Bokova $(n=40)$ & Ekona $(n=44)$ & Bonduma $(n=32)$ & $P$-values & \\
\hline Stem borers & $94.3 \pm 3.7 a$ & $97.5 \pm 2.5 a$ & $70.5 \pm 7.3 b$ & $65.6 \pm 7.6 b$ & $<0.0001$ & $82.1 \pm 6.1$ \\
\hline Weevils & $5.7 \pm 3.7 b$ & $10.0 \pm 4.8 b$ & $13.6 \pm 5.5 b$ & $40.6 \pm 7.8 \mathrm{a}$ & $<0.0001$ & $16.6 \pm 5.9$ \\
\hline Snails & $2.9 \pm 2.7 b$ & 0 & $18.2 \pm 6.2 \mathrm{a}$ & $3.1 \pm 2.8 b$ & $<0.0001$ & $6.6 \pm 3.9$ \\
\hline Thieves (Human) & 0 & $7.5 \pm 4.2$ & 0 & 0 & $<0.0001$ & $1.9 \pm 2.2$ \\
\hline White grubs & $2.9 \pm 2.7 b$ & 0 & $13.6 \pm 5.5 b$ & $37.5 \pm 7.7 \mathrm{a}$ & $<0.0001$ & $11.9 \pm 5.2$ \\
\hline Birds & $2.9 \pm 2.7 b$ & $5.0 \pm 3.5 b$ & $4.6 \pm 3.3 b$ & $25 \pm 6.9 a$ & $<0.0001$ & $8.6 \pm 4.5$ \\
\hline \multicolumn{7}{|l|}{ Females } \\
\hline Stem borers & $100 a$ & $95.8 \pm 3.2 \mathrm{a}$ & $71.4 \pm 7.2 \mathrm{~b}$ & $70.6 \pm 7.3 b$ & $<0.0001$ & $83.6 \pm 5.9$ \\
\hline Weevils & 0 & $12.5 \pm 5.3 b$ & $11.9 \pm 5.2 b$ & $41.2 \pm 7.9 a$ & $<0.0001$ & $13.6 \pm 5.5$ \\
\hline Snails & 0 & 0 & $16.7 \pm 5.9$ & 0 & $<0.0001$ & $6.4 \pm 3.9$ \\
\hline Thieves (Human) & 0 & $4.2 \pm 3.2$ & 0 & 0 & $<0.0001$ & $0.9 \pm 1.5$ \\
\hline White grubs & 0 & 0 & $14.3 \pm 5.6 b$ & $47.1 \pm 7.9 a$ & $<0.0001$ & $12.7 \pm 5.3$ \\
\hline Birds & 0 & $8.3 \pm 4.4 b$ & $4.8 \pm 3.4 b$ & $17.7 \pm 6.1 \mathrm{a}$ & $<0.0001$ & $6.4 \pm 3.9$ \\
\hline \multicolumn{7}{|l|}{ Males } \\
\hline Stem borers & $75 \pm 6.9 b$ & $100 a$ & $50 \pm 7.9 c$ & $60 \pm 7.8 b$ & 0.0003 & $78.1 \pm 6.6$ \\
\hline Weevils & $25 \pm 6.9 b$ & $6.3 \pm 3.9 b$ & $50 \pm 7.9 a$ & $40 \pm 7.8 a$ & 0.0010 & $24.4 \pm 6.8$ \\
\hline Snails & $12.5 \pm 5.3 b$ & 0 & $50 \pm 7.9 a$ & $6.7 \pm 3.9 b$ & $<0.0001$ & $7.3 \pm 4.2$ \\
\hline Thieves (Human) & 0 & $12.5 \pm 5.3$ & 0 & 0 & $<0.0001$ & $4.9 \pm 3.4$ \\
\hline White grubs & $12.5 \pm 5.3 a$ & 0 & 100 & $26.7 \pm 7.1 \mathrm{a}$ & $<0.0001$ & $9.8 \pm 4.7$ \\
\hline Birds & $12.5 \pm 5.3 b$ & 0 & 0 & $33.3 \pm 7.5 a$ & $<0.0001$ & $14.6 \pm 5.6$ \\
\hline
\end{tabular}

\section{Indigenous knowledge and efficacy of plant-based control}

The survey showed some knowledge on use of indigenous methods for maize pests and diseases control (Table 4). $54.30 \%$ of the total respondents admitted not having any indigenous knowledge, while $45.70 \%$ used indigenous methods to combat stem borers. In Ekona, Bonduma and Maumu, 72.73 \%, $43.75 \%$ and $40 \%$ respectively of respondent used indigenous method as against $22.50 \%$ in Lower Bokova. Within each village, males and females had different perceptions on indigenous control methods; $76.91 \%$ of females in Ekona used indigenous control against zero males. In Lower Bokova and Bonduma, more males than females used indigenous control, while in Maumu more females (44.44\%) than males (25\%) used indigenous control.

Only $18.54 \%$ of farmers in this region had any knowledge on the use of plant derivatives in place of chemicals, while $81.46 \%$ have never used any plant product as control against stem borers. However, 37.04 \% females used plants as against $12.50 \%$ of males in Maumu, while 38.10 \% used plants in Ekona. In Lower Bokova, males and females did not use plants, while in Bonduma $6.67 \%$ of males used plant products. The use of plant-based products was low in some villages because most of the farmers depended on synthetic (Table 4). In Ekona, Lower Bokova, Maumu, Bonduma, 63.64 \%, 100 \%, $68.57 \%$ and $96.88 \%$, respectively of respondents do not used any plant materials for control.

Some respondent used wood ash as an indigenous control method (Ekona), and rated it to be very effective. The wood ash was sometimes mixed with Mocap (ethopropos), which is a synthetic product. The only problem was that most of them could not recognize the particular plant or the parts of the plant being used or even the proportion and formulations.

\section{Indigenous methods of stem borer control in the Region}

Various indigenous control methods were enumerated by the farmers. The main ingredient in most of them was ash collected from household kitchens or burnt wood (Fig. 1). Some used only the dry wood ash while others mixed fine dry soil with wood ash. Some others mixed their ash with conventional insecticides such as Mocap (ethopropos), Sevin, Gamalin or Kerosene. Some mixed the ash with water or Kerosene and used as sprays. In all of these methods, treatment was applied within the leaf whorl of the plant without any personal 
Table 4 Percentage $( \pm \mathrm{i})$ respondent relative to use of plant-based/indigenous stem borer control in Fako Division of the South Western Cameroon

\begin{tabular}{|c|c|c|c|c|c|c|}
\hline \multicolumn{6}{|l|}{ All } & \multirow[t]{2}{*}{ Overall } \\
\hline Control of stem borers & & Maumu $(n=35)$ & Lower Bokova $(n=40)$ & Ekona $(n=44)$ & Bonduma $(n=32)$ & \\
\hline \multirow[t]{3}{*}{ Plant-based products } & Yes & $31.4 \pm 7.4 a$ & 0 & $36.4 \pm 7.7 a$ & $3.1 \pm 2.8 b$ & $18.5 \pm 6.2$ \\
\hline & No & $68.6 \pm 7.4 b$ & 100 & $63.6 \pm 7.7 b$ & $96.9 \pm 2.8 \mathrm{a}$ & $81.5 \pm 6.2$ \\
\hline & $P$-values & 0.0280 & 0 & 0.0704 & $<0.0001$ & $<0.0001$ \\
\hline \multirow[t]{3}{*}{ Other indigenous methods } & Yes & $40 \pm 7.8 b$ & $22.5 \pm 6.7 b$ & $72.7 \pm 7.1 a$ & $43.8 \pm 7.9 b$ & $45.3 \pm 7.9$ \\
\hline & No & $60 \pm 7.8 \mathrm{a}$ & $77.5 \pm 6.7 a$ & $27.3 \pm 7.1 b$ & $56.3 \pm 7.9 a$ & $54.7 \pm 7.9$ \\
\hline & $P$-values & 0.2367 & 0.0005 & 0.0026 & 0.4795 & 0.2901 \\
\hline \multicolumn{7}{|l|}{ Females } \\
\hline \multirow[t]{3}{*}{ Plant-based products } & Yes & $37.0 \pm 7.7 a$ & 0 & $38.1 \pm 7.8 \mathrm{a}$ & 0 & $23.6 \pm 6.8$ \\
\hline & No & $62.9 \pm 7.70 \mathrm{a}$ & 100 & $61.9 \pm 7.8 \mathrm{a}$ & 100 & $73.4 \pm 7.1$ \\
\hline & $P$-values & 0.1779 & NA & NA & NA & $<0.0001$ \\
\hline \multirow[t]{3}{*}{ Other indigenous methods } & Yes & $44.4 \pm 7.9 b$ & $20.8 \pm 6.5 b$ & $76.2 \pm 6.8 a$ & $41.2 \pm 7.9 b$ & $50.9 \pm 7.9$ \\
\hline & No & $55.6 \pm 7.9 a$ & $79.2 \pm 6.5 a$ & $23.8 \pm 6.8 b$ & $58.8 \pm 7.9 a$ & $49.1 \pm 7.9$ \\
\hline & $P$-values & 0.5637 & 0.0043 & 0.0007 & 0.4669 & 0.8488 \\
\hline \multicolumn{7}{|l|}{ Males } \\
\hline \multirow[t]{3}{*}{ Plant-based products } & Yes & $12.5 \pm 5.3$ & 0 & 0 & $6.7 \pm 3.9$ & $4.9 \pm 3.4$ \\
\hline & No & $87.5 \pm 5.3 a$ & 100 & 100 & $93.3 \pm 3.9 a$ & $95.1 \pm 3.4$ \\
\hline & $P$-values & 0.0339 & NA & NA & 0.0008 & $<0.0001$ \\
\hline \multirow[t]{3}{*}{ Other indigenous methods } & Yes & $25 \pm 6.9 b$ & $25 \pm 6.9 b$ & 0 & $46.7 \pm 7.9 a$ & $31.7 \pm 7.4$ \\
\hline & No & $75 \pm 6.9 a$ & $75 \pm 6.9 a$ & 100 & $53.3 \pm 7.9 b$ & $68.3 \pm 7.4$ \\
\hline & $P$-values & 0.1573 & 0.0455 & NA & 0.7963 & 0.0191 \\
\hline
\end{tabular}

protective equipment (PPE). This raises safety concern for persons doing the applications. To keep away other larger insects and birds, farmers hang torn plastic bags, old plastic buckets in and around their fields especially just after planting (Fig. 2). Other farmers just simply let go and face the consequences of their maize being

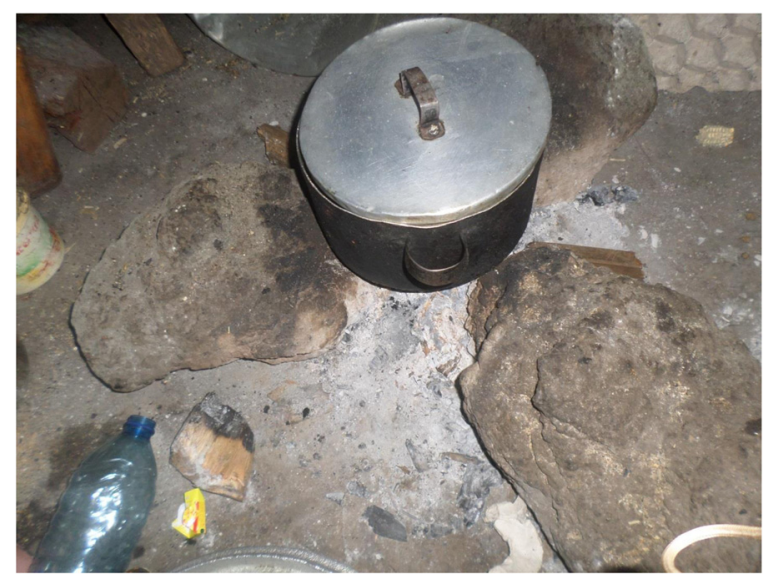

Fig. 1 Typical local kitchen with three-stone fire place where wood ash is collected destroyed by these pests thus reducing average yields. Sometimes the birds fed on the cobs when the maize was matured. To remedy such situations, some farmers tied the leaves closest to the cobs around the cob to prevent the birds from feeding on the grains (Fig. 3).

\section{Use of pesticides}

In all four villages surveyed, $70.20 \%$ of respondents used pesticides to treat their maize farms and $29.80 \%$ did not (Table 5). More farmers in Buea used conventional pesticides, especially Cypercal 12 than those in Muyuka; most of their treatments were applied in the month of September

More farmers in Ekona (79.55 \%) and Lower Bokova (95\%) depended on pesticide compared to Bonduma (40.63 \%) and Maumu (57.14 \%). In Maumu, more males $(87.50 \%)$ than females $(48.15 \%)$ used pesticides while in Ekona and Lower Bokova, all males (100 \%) used pesticides as against $91.67 \%$ and $78.57 \%$ of females respectively (Table 5).

Cypercal 12 was the main pesticide used in Lower Bokova (52.50 \%), while Mocap (Ethopropos) was widely used by all farmers, especially in Ekona (43.18 \%) (Fig. 4). Mocap (Ethopropos), an organophosphate insecticide was 


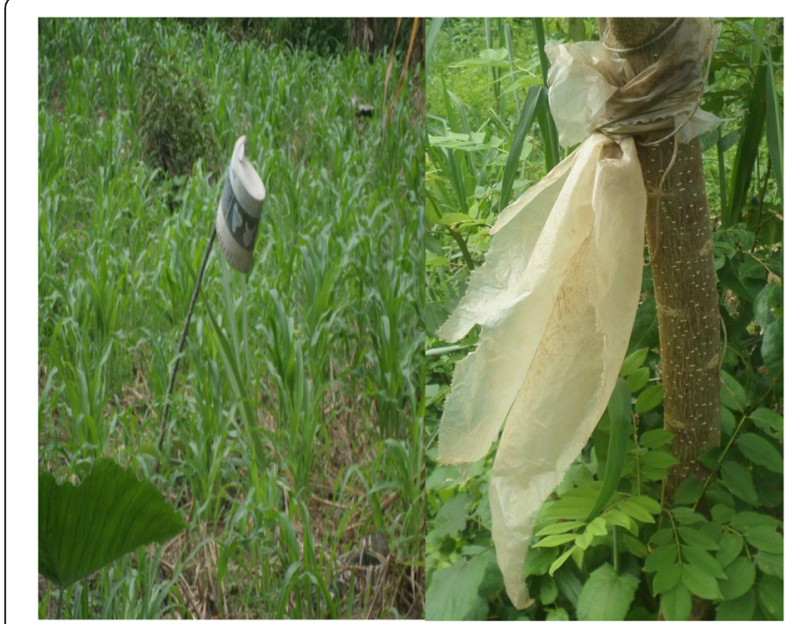

Fig. 2 Typical maize farm with torn plastic bags and old plastic buckets tied to keep away birds

widely used because it was cheaper and easy to get, and is also a contact/repellent product. About $53.13 \%$ of farmers in Bonduma did not use any of the pesticides, though sometimes they got advice from friends on the type of pesticide to use. Some farmers admitted not using any pesticides against stem borers, but sometimes used weed killers, since maize does not tolerate high weed population. Some farmers mixed Mocap (Ethopropos) and wood ash, where the wood ash serves as a carrier substance for the insecticide.

The main constraints reported by the farmers regarding the use of pesticides were high prices (72.19\%), while $27.15 \%$ were indifferent (Fig. 5). In Lower Bokova, $82.50 \%$ of farmers complained of high prices, since most of them depended on pesticides. Some of their

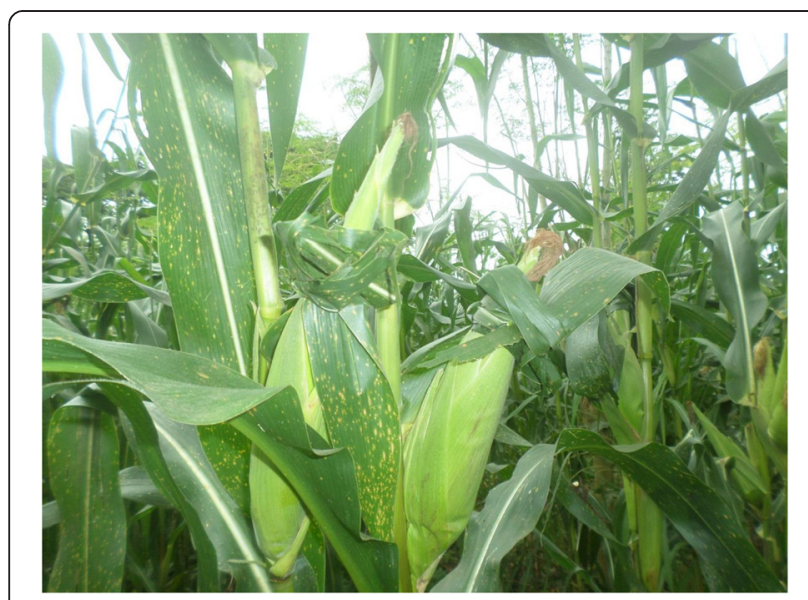

Fig. 3 Typical indigenous traditional method for keeping away birds from feeding on the matured maize cobs before harvest proposed solutions to these constraints were; need for government subsidies, prices should be moderated in the market and the need for alternative methods of stem borer control (Fig. 6). In Ekona, 61.36 \% of farmers believed government subsidies would help resolve the problem of high prices. Others believed pesticides were easier and quicker to administer on farm. More than $50 \%$ of respondents in the four villages proposed government subsidies and price reduction as solutions to the pesticide constraints.

\section{Farmers' future preference}

Regarding farmers' future preferences, more of them in Muyuka would prefer the continued use of conventional methods of stem borer control than in Buea. Due to the high level of education and the cosmopolitan nature of Buea, most of the farmers had lost their indigenous knowledge than in Muyuka. They had no basic knowledge on indigenous methods of plants used for pest control.

Most farmers did not have contacts with agricultural extension workers because the few extension workers could hardly visit all the farmers in their areas. This was a major constraint to the farmers since they were not well informed about insecticides and common indigenous methods of pest control. Most of the farmers (88.74\%) expressed interest in the use of plant-based products (Fig. 7). More farmers in Lower Bokova (97.50 \%) were willing to try plant-based insecticides than in Bonduma (84.38 \%), Ekona (88.64\%) and Maumu (82.86 \%). Some of the reasons mentioned were that the plants were safer than synthetic insecticides and also readily available. Others sought to know whether such plants could have long-term effects and were not time-consuming. The remaining $11.26 \%$ did not show any interest in the use of plant products.

When questioned on their future preferences, $60.26 \%$ declared that they would prefer plant products in place of synthetic insecticides, $8.61 \%$ preferred both synthetic and indigenous, $26.49 \%$ still preferred conventional insecticides while $4.64 \%$ were undecided (Fig. 8). Lower Bokova again showed that more farmers (80\%) would prefer plant-based insecticides as compared to Ekona (47.73 \%), Maumu (60\%) and Bonduma (53.13\%). Those who preferred synthetic insecticides believed that if the government could subsidize or reduce the cost of these products in the market, they will be able to afford them. The role of the Ministry of Agriculture is still preponderant as it grants the import authorization and approves the distribution and sales of the agricultural inputs. Some of the study villages are far from the sales point. Consequently, transportation costs rendered costs of inputs out of the reach of many farmers. 
Table 5 Percentage $( \pm \mathrm{i})$ respondent relative to use of pesticides in Fako Division of South Western Cameroon

\begin{tabular}{|c|c|c|c|c|c|}
\hline \multicolumn{5}{|l|}{ All } & \multirow[t]{2}{*}{ Overall } \\
\hline Conventional methods & Maumu $(n=35)$ & Lower Bokova $(n=40)$ & Ekona $(n=44)$ & Bonduma $(n=32)$ & \\
\hline Use pesticides & $57.1 \pm 7.9 b$ & $95 \pm 3.5 a$ & $79.6 \pm 6.4 a$ & $40.6 \pm 7.8 b$ & $70.2 \pm 7.3$ \\
\hline Do not use pesticides & $42.9 \pm 7.9 a$ & $5 \pm 3.5 b$ & $20.5 \pm 6.4 b$ & $59.4 \pm 7.8 \mathrm{a}$ & $29.8 \pm 7.3$ \\
\hline P-values & 0.3980 & $<0.0001$ & $<0.0001$ & 0.2888 & $<0.0001$ \\
\hline \multicolumn{6}{|l|}{ Females } \\
\hline Use pesticides & $48.2 \pm 7.9 b$ & $91.7 \pm 4.4 a$ & $78.6 \pm 6.6 \mathrm{a}$ & $35.3 \pm 7.6 b$ & $67.3 \pm 7.5$ \\
\hline Do not use pesticides & $51.9 \pm 7.9 a$ & $8.3 \pm 4.4 b$ & $21.4 \pm 6.6 b$ & $64.7 \pm 7.6 a$ & $32.7 \pm 7.5$ \\
\hline P-values & 0.8474 & $<0.0001$ & 0.0002 & 0.2253 & 0.0003 \\
\hline \multicolumn{6}{|l|}{ Males } \\
\hline Use pesticides & $87.5 \pm 5.3 \mathrm{a}$ & 100 & 100 & $46.7 \pm 7.9 b$ & $78.1 \pm 6.6$ \\
\hline Do not use pesticides & $12.5 \pm 5.3 b$ & 0 & 0 & $53.3 \pm 7.9 a$ & $21.9 \pm 6.6$ \\
\hline$P$-values & 0.0339 & NA & NA & 0.7963 & 0.0003 \\
\hline
\end{tabular}

\section{Discussion}

Apart from food crops, farmers in Fako division of South West Region of Cameroon also grow cash crops and also rare animals for home consumption. Most of the crops are attacked by field pests during the rainy season when crops are in the vegetative and reproductive stages; this greatly reduces the farmers' harvests. Most of the pests problems encountered are on cereals, particularly maize. Crop products are stored as food reserves in these areas, while some of the produce are used for income generation. Considering that the maize yields are always low, partly due to pests/diseases and other allied constraints, it has serious implications on their food security needs.

Land, labour, finance, pests and diseases were the most important constraints to maize production in the Fako division of the South West region of Cameroon. As is the case in most parts of Africa [30], most of the smallholders' farmers in Cameroon are women with twothirds of their farms being below 2 hectares. Many practice low-resource agriculture based primarily on the use of local resources with modest external inputs. Increased urbanization causes a shift of farmland into urban areas, thus reducing available space for farming [31]. The

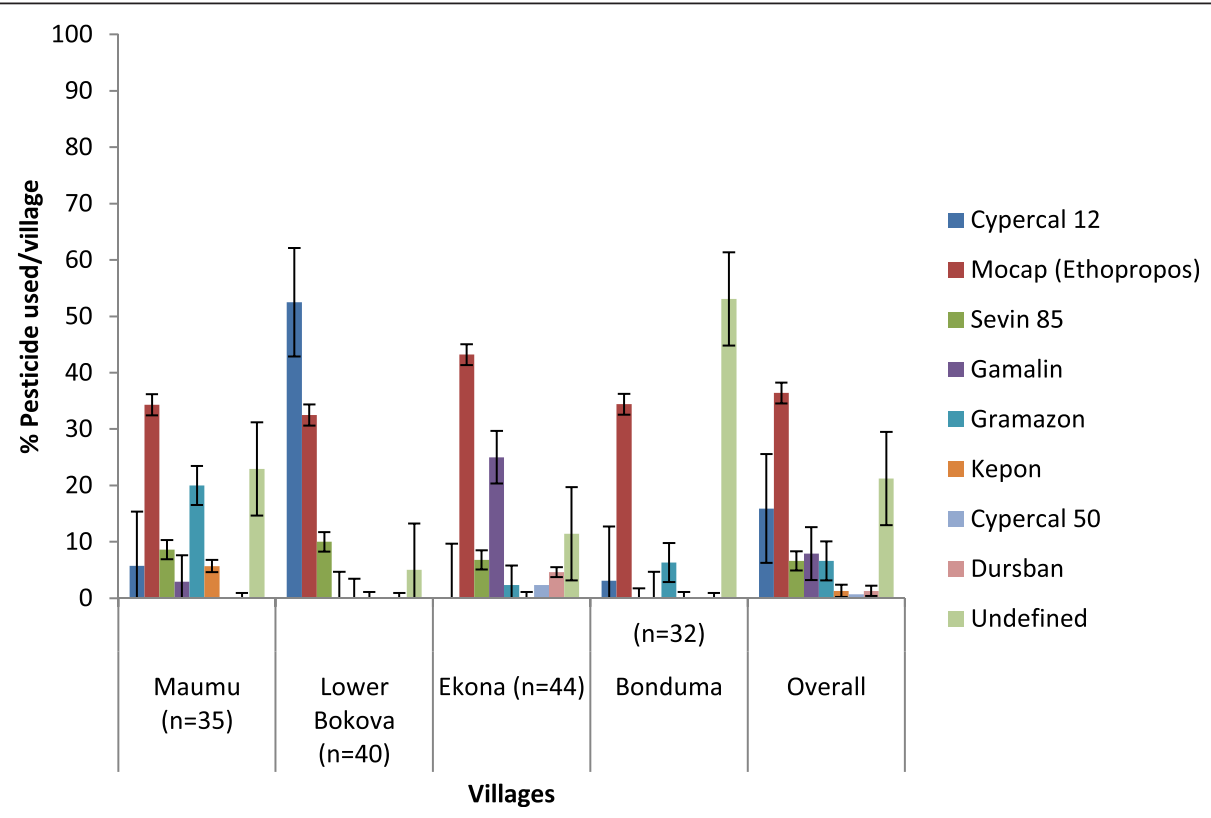

Fig. 4 Percentage $( \pm \mathrm{i})$ respondent relative to main pesticides used in Fako division of the South Western Cameroon 


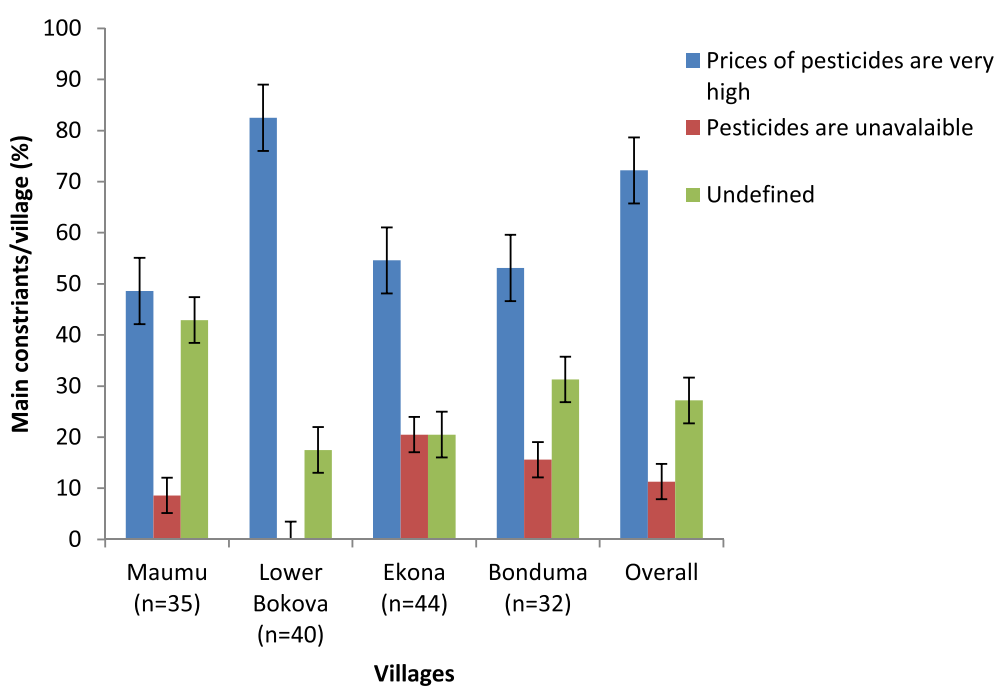

Fig. 5 Percentage $( \pm \mathrm{i})$ respondent relative to main constraints faced in Fako division of South Western Cameroon

quantity of available land and farm inputs determine maize output. Similar results were obtained by [32] in the West region of Cameroon, stating that, maize yields were low due to reduced farm sizes, low quality of maize seeds planted, inadequate labour, fertilizer and agrochemicals inputs. Most of the food production burden falls on women and children because of rural urban migration and reduction in active work force wreaked by various diseases and ill-health [33]. Children are sometimes denied the chance to go to school to assist in weeding because of labour scarcity, resulting in low educational performance [34]. Pest and diseases were the major constraints limiting attainable

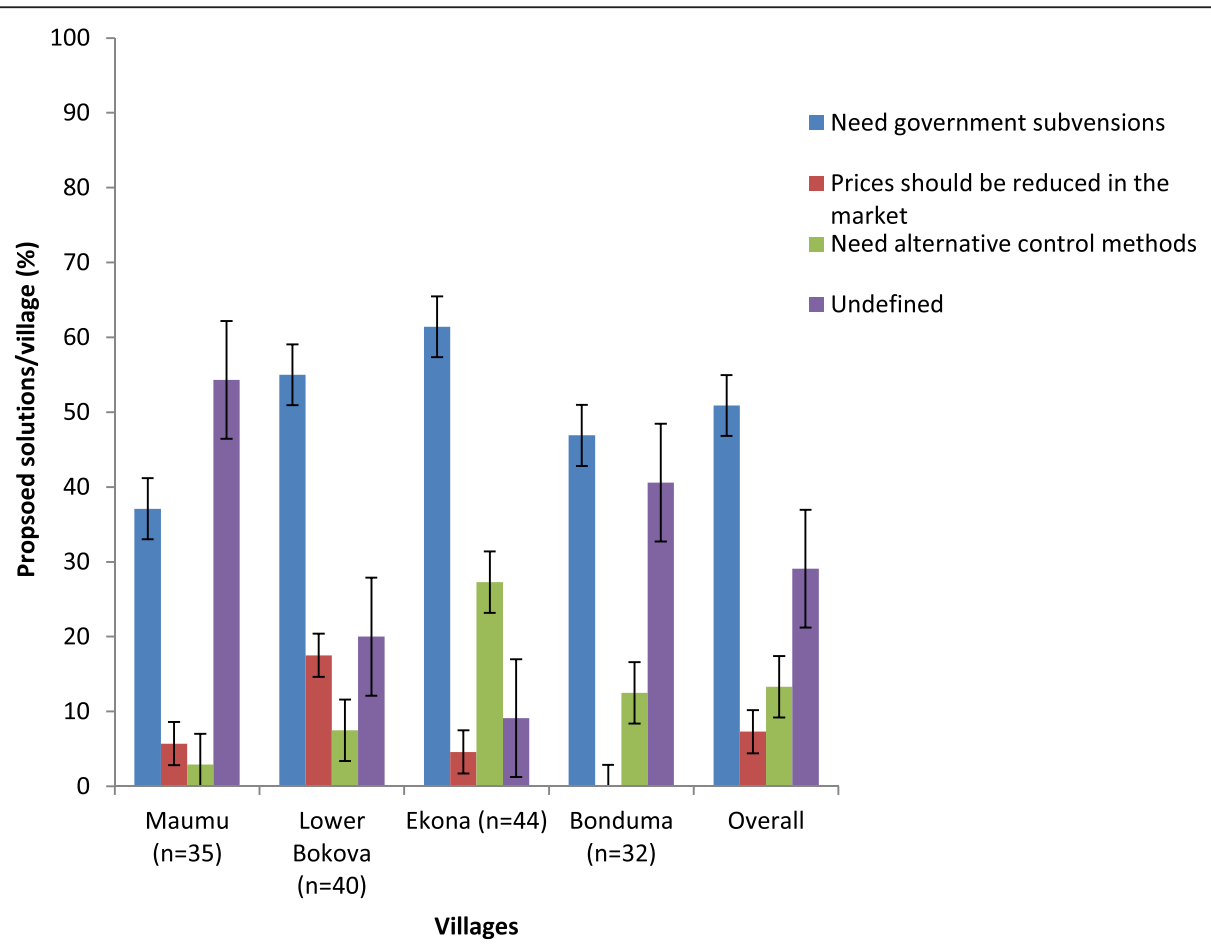

Fig. 6 Percentage $( \pm \mathrm{i})$ respondent relative to possible solutions proposed to constraints in Fako division of South Western Cameroon 


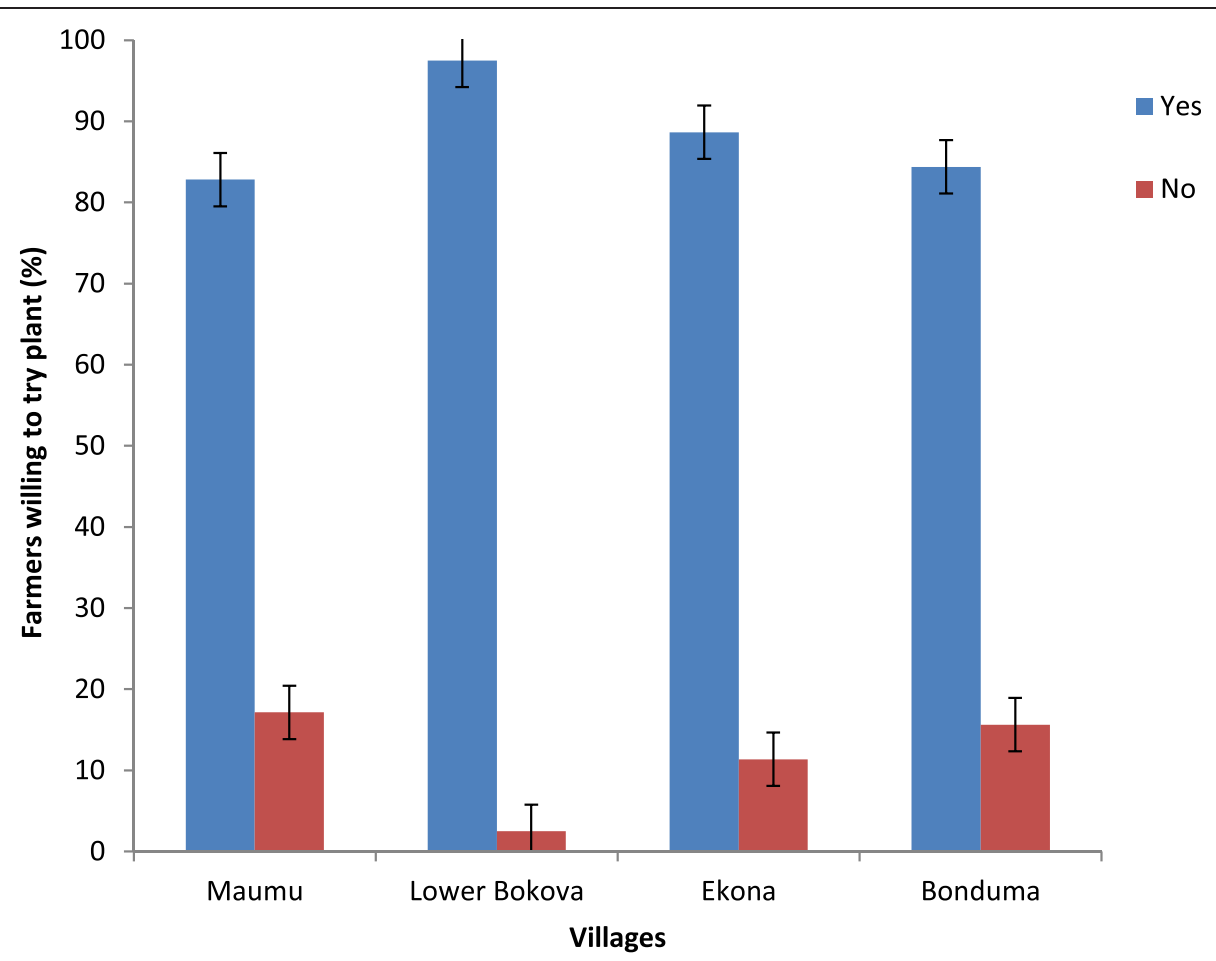

Fig. 7 Percentage of maize farmers in Fako division willing to try plant-based insecticides control methods

maize yields. In the farmers' perceptions, pest and diseases were amongst the most important constraints in crops in this region. Most of them showed some degree of awareness of the different insect pests that attack their crops. Similar results were reported by [32] in the forest and humid forest of Cameroon, which corroborates with the findings of [35]. Increase in pest and disease may partly be as a result of increased use of pesticides by larger corporations which makes the pest become resistant and later shift into the untreated fields.

The study showed that the farmers regarded stem borers as important pests of maize in Fako division of

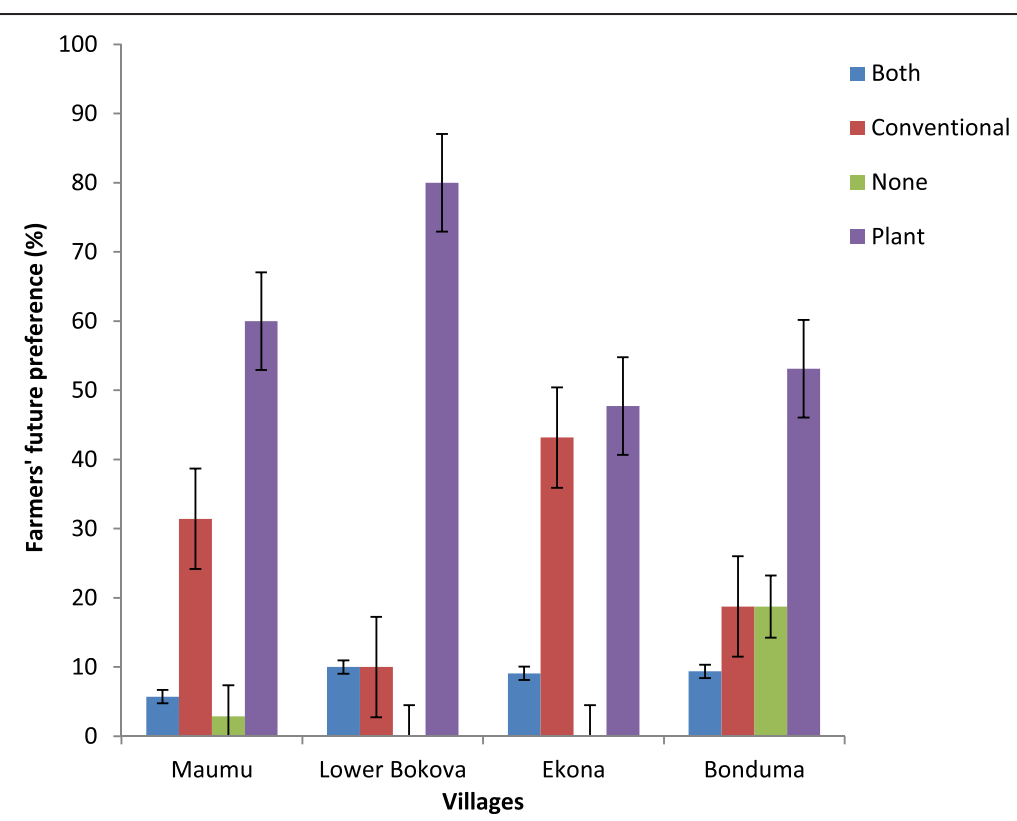

Fig. 8 Percentage of maize farmers in Fako division who prefers plant-based insecticide control against conventional products in future 
the South West Cameroon. Stem borers interfere with the movement of water and metabolites through the plant's vascular system, which stunts its growth and development. Attacks during the first eight weeks after sowing result in "dead heart" and late damage (beyond eight weeks after sowing) leads to stem lodging. Both types of damage to the crop cause drastic loss in maize yield [36]. The farmers reported an increased damage during the dry season when pest populations are higher. Farmers' perceived that, the insect pests had economic implications, given that the insects caused significant damage that warranted the implementation of control measures. These perceptions contribute to the understanding of various aspects of the bio-ecology of insect pests $[36,37]$. Similar results were also obtained in the humid forest and Western highlands of Cameroon [38-40].

The results indicated that only $45.70 \%$ of the farmers used one indigenous method or another, while $54.30 \%$ depended solely on conventional control methods, which are expensive. Some reported that indigenous methods were time-consuming and they were not sure of the results. Those who used indigenous methods believed they were cheaper and they faced no problems with their use. Cultural/indigenous practices are not expensive for the farmers and do not necessitate in general, supplementary material investments to control insect pests [41]. A large proportion of the farmers believed indigenous control methods are not effective similar to the findings of [41], which stated that the development of traditional/indigenous control methods is very limited.

The results showed that very few farmers were using plants as insect pest control methods in their fields. Farmers perceived plant derivatives could not give the desired results achieved when conventional methods are used. Possibly integrating the use of resistant plants with plant derivatives could be a better option for replacing synthetic chemicals, given that they are simple, economical and important strategies in insect pest control. They are also not dangerous to the environment and are generally compatible with other pest control methods $[11,41]$. Farmers' knowledge and perception of their use can accelerate and facilitate their adoption in the local communities.

More farmers depended on pesticides than on botanical control, although not adequately informed about their proper use similar to studies carried out by the Ministry of Agriculture which showed that more than $42 \%$ of farmers use pesticides [42]. Increased use of pesticides is due to the proliferation and accessibility of unlicensed dealers' shops that are only out to make money but care less about the consequences of pesticides. Farmers relied mostly on estimations for the amount and concentration required for a given botanical pesticide formulation because most of them are illiterate.
Therefore, there might be risk of overdose, since most of them do not have frequent contacts with extension workers. The most mentioned pesticides used by farmers are Mocap (Ethopropos) and Cypercal. The former, being the cheapest and readily available while the latter, classified as " $1 \mathrm{~b}$ " by the World Health Organization (WHO) and qualified as highly dangerous [42] is no longer recommended [43]. Mocap (Ethopropos) is an organophosphate (classified as IA), extremely hazardous to eyes, and the body when inhaled especially as farmers donot use personal protective equipments (PPE) during pesticide applications. Most of these insecticides are also highly dangerous to the environment and pollute water bodies. Substances classified in these category by WHO should not be applied by untrained or inadequately protected people [44-46].

Indigenous control methods were important because most of the farming in these areas are subsistence. Despite the fact that most of the farmers acknowledge the effectiveness of plant-based insecticides, most of them would still prefer conventional products in future if they are affordable. This may be because those who use the indigenous controls and botanicals do not know the right formulations and amounts to apply, as well as the time of application. The main component of this indigenous control was ash from burnt wood collected from local kitchens. Owolabi et al. [29] studied the effect of liming materials such as plant derived ash on maize yield, and found that it increased soil $\mathrm{pH}$ and maize yield.

The findings showed that there was heterogeneity in knowledge between the two locations as well as in gender respectively. In most of the responses, the women seemed to perceive the pest incidences with equal importance. Most of the males interviewed were from Lower Bokova (17), followed by Bonduma (14) which are villages in Buea with a higher level of education. While most of the females were found in Ekona (42) and Maumu (27) and farming was their main occupation without any formal education. This confirms why their perceptions were different, as more women than men reported increased incidence of stem borers in their fields. Perception differences in gender have also been observed in Nepal, where men generally used more vague attributes like harmful or harmless, while women were more specific, regarding the depredatory insects [37]. Gender differences in perception may also be due to division of labour, as most of the women in this region spend equal time in fields as well as household tasks while the men are involved in farming and community works.

In absence of a standardized protocol on preparation and application, the indigenous plant-based formulations will have varied efficacies at different times even with the same farmer. Without the standardization of the specific amount of a product used, exposure time and 
way of preparation and no proper application rate and method, efficacy rating of any pesticide will be compromised. There is therefore need to increase productivity through the development of alternative low-cost plantderived technologies for fighting pests and diseases in crop fields. Studies in China showed that some of these plants, such as the leaves and twigs of Tephrosia vogelii do possess strong antifeedant stomach poison and growth inhibiting effects against many insect pests, including the stem borers [47].

Therefore, if the use of ash and other plant derivatives are exploited further and their qualities improved and quantified these will be of great use to the resource-poor farming communities in this region. Most especially if the particular plant is known for its insect control potentials.

\section{Conclusions}

Findings from the survey reveal that farmers in Fako division practiced subsistence agriculture with maize as one of the major crops. The maize is always grown in a mixed cropping system and stem borers are the major field pests limiting attainable yield. The pest burden is greatest during the dry season. Besides maize and other food crops, some farmers also grow cash crops and rare animals for home consumption. Most farmers in the study villages depend on the use of synthetic pesticides to control stem borers. Farmers have limited knowledge of indigenous methods of stem borer control over synthetic, but would prefer it in the future if well informed. This is because, the indigenous and/or plant based pest control methods would be cheaper and readily available as well as being safer if accompanied by standardized methods as well bio-safety and environmental guidelines for efficacy. Farmers would prefer an integrated approach to pest control since it contributes all possible strategies to reduce the pest burden. There was a wide perceptional difference in gender and location similar to most studies. This may differ from scientific studies, but having significant implications for development [32]. To ensure quality and safety, biosafety and quality studies are required for quality assessment of resulting product for human health.

\section{Abbreviations \\ ASWA-RUDEP: Association of South West agriculturist rural development project; M: Metre; Asl: Above sea-level; PAN: Pesticide action network; WHO: World Health Organization; PPE: Personal protective equipment; IPM: Integrated pest management.}

\section{Competing interests}

The authors declare that they have no competing interests.

\section{Authors' contributions}

EOO main author, involved in the study design, conducted interviews, literature review and general data collection, wrote the first draft and concluded the final version of this manuscript. NNN main coordinator-supervisor of the research project; contributed with original data and the designing of all the researches; participated in reviewed several drafts of the manuscript. SK has participated in the improvement of the literature review; has done data analysis and interpretation; has corrected the first draft and reviewed several drafts of the manuscript. MNA (Director of ASWA-RUDEP), contributed to introduce the main author to various farmers' group to conduct interviews with help of extension workers. All authors read and approved the final manuscript.

\section{Authors' information}

EOO is Assistant Lecturer (University of Yaoundé 1) and PhD student (University of Buea). NNN Associate Professor (University of Buea). SK Senior Lecturer (University of Yaoundé 1). MNA Executive Director of South West Agriculturist Rural Development Projects (ASWA-RUDEP).

\section{Acknowledgement}

This study was supported with resource persons from ASWA-RUDEP Association of South West agriculturist rural development project, delegation of agriculture, South West Region, Buea and the University of Buea. Special thanks go to the population of the studied villages for their valuable contribution to the survey.

\section{Author details}

${ }^{1}$ Department of Animal Biology and Physiology, Faculty of Science, University of Yaounde 1, P. O. Box 812, Yaounde, Cameroon. ${ }^{2}$ Department of Zoology and Animal Physiology, Faculty of Science, University of Buea, Buea, Cameroon. ${ }^{3}$ Association of South West Agriculturist Rural Development Project (ASWA-RUDEP), Buea, South West Region, Cameroon.

Received: 26 May 2014 Accepted: 15 October 2015

Published online: 09 November 2015

\section{References}

1. Dewbre J, BorotdeBattisti A. Agricultural progress in Cameroon Ghana and Mali: why it happened and how to sustain it. OECD Food Agric Fish Working Papers. 2008;9:60.

2. Van den Berg J. Bt-Resistant Target Pests - Quick Occurrence in South Africa. Advancing the Understanding of Biosafety Latest scientific findings, policy responses and public participation. South Africa: North-West University; 2010.

3. Polaszek A: African cereal stemborers, economic importance, taxonomy, natural enemies and control. CAB International in association with the ACP-EU Technical Centre for Agricultural and Rural Co-operation (CTA); 1998.

4. Ndemah R. Towards an integrated crop management strategy for the African stalk borer, Busseola fusca Fuller. Lepidoptera: Noctuidae. in maize systems in Cameroon. University of Hannover, Germany: Ph.D thesis; 1999.

5. Chabi-Olaye A, Nolte C, Schulthess F, Borgemeister C. Effects of grain legumes and cover crops on maize yield and plant damage by Busseola fusca (Fuller) (Lepidoptera: Noctuidae) in the humid forest of southern Cameroon. Agric Ecosyst Environ. 2005;108:17-28.

6. Chabi-Olaye A, Nolte C, Schulthess F, Borgemeister C. Abundance, dispersion and parasitism of the noctuid stem borer Busseola fusca (Fuller) in mono- and intercropped maize in the humid forest zone of southern Cameroon. Bull Entomol Res. 2005;95:169-77.

7. Ajala SO, Aroga R, Odiyi A, Olaoye G. Screening and breeding for resistance to maize stem borers and Eldana in West and Central Africa. African Crop Science Society. 2009;9:559-64.

8. Bosque-Perez NA, Mareck JH. Effect of the stem borer Eldana saccharina (Lepidoptera: Pyralidae) on the yield of maize. Bull Entomol Res. 1991:81:243-7.

9. Cardwell KF, Schulthess F, Ndemah R, Ngoko Z. A systems approach to assess crop health and maize yield losses due to pests and diseases in Cameroon. Agric Ecosyst Environ. 1997;65:33-47.

10. Sétamou M, Schulthess F, Poehling HM, Borgemeister C. Infestations and damage of maize by Mussidia nigrivenella Ragonot (Lepidoptera: Pyralidae) in Benin, West Africa. J Econ Entomol. 2000;93:650-7.

11. Aslam M, Ali KK, Bajcoa MZH. Potency of some spices against Callosobruchus chinensis Linnaeus. Online J Biol Sci. 2002;2 Suppl 7:449-52.

12. Granados G. Maize Insects. In: Paliwal RL, Granados G, Lafitte R, Violic AD, Marathee JP, editors. Tropical Maize Improvement and Production. FAO Plant Production and Protection Series 28. Rome: Food and Agriculture Organization (FAO); 2000.

13. Seshu Reddy KV. Cultural control of Chilo spp. in graminaceous crops. Insect Sci Appl. 1990;11:703-12. 
14. Van den Berg J, Nur AF, Polaszek A. Cultural control. See Ref. 1998;150:333-47.

15. Kfir R, Overholt WA, Khan ZR, Polaszek A. Biology and management of Economically Important Lepidopteran Cereal Stem Borers in Africa. Annu Rev Entomol. 2002:47:701-31.

16. Mugisha-Kamatenesi M. Medicinal Plants used in Reproductive Health Care in Western Uganda: Documentation, Phytochem. And Bioactivity Evaluation. Makerere University, Kampala, Uganda: PhD thesis; 2004.

17. Mihale MJ, Deng AL, Selemani HO, Mugisha-Kamatenesi M, Kidukuli AW Ogendo JO. Use of indigenous knowledge in the management of field and storage pests around Lake Victoria basin in Tanzania. Afr J Environ Sci Technol. 2009:3 Suppl 9:251-9.

18. Darwish RM, Aburjai TA. Effect of ethnomedicinal plants used in folklore medicine in Jordan as antibiotic resistant inhibitors on Escherichia coli. BMC Complement Altern Med. 2010;10:109-16

19. Hegazy AK, Alatar AA, Thomas J, Faisal M, Alfarhan AH, Krzywinski K. Compatibility and complementarity of indigenous and scientific knowledge of wild plants in the highlands of southwest Saudi Arabia. J Forest Res. 2014;25 Suppl 2:437-44.

20. Mugisha-Kamatenesi M, Deng AL, Ogendo JO, Omolo EO, Mihale MJ, Otim M, et al. Indigenous Knowledge of field insect Pests and their Management around Lake Victoria basin in Uganda. Afr J Environ Sci Technol. 2008;2 Suppl 8:342-8.

21. Ogendo JO, Belmain SR, Deng AL, Walker DJ. Comparison of toxic and repellent effects of Lantana camara L. with Tephrosia vogelii Hook and a synthetic pesticide against Sitophilus zeamais Motsch. (Coleoptera: Curculionidae) in stored maize grain. Insect Sci Appl. 2003;23 Suppl 2:127-35.

22. Bekele AJ, Obeng-Ofori D, Hassanali A. Evaluation of Ocimum kenyense (Ayobangira) as source of repellent, toxicants, and protectants in storage against three major stored products insect pests. J Appl Entomol. 1997;121:169-73.

23. Ogendo JO, Kostyukovsky M, Ravid U, Matasyoh JC, Deng AL, Omolo EO, et al. Bioactivity of Ocimum gratissimum L. oil and two of its constituents against five insect pests attacking stored food products. J Stored Prod Res. 2008;44:328-34.

24. Ntonifor NN, Monah MI. Use of three spices to protect stored maize against Sitophilus zeamais. Trop Sci. 2001;41:74-7.

25. Ntonifor NN, Esther OO, Konje CB. Use of selected plant-derived powders and their combinations to protect stored cowpea grains against damage by Callosobruchus maculatus. J Agric Biol Sci. 2010;5 Suppl 5:13-21.

26. Ntonifor NN. Potentials of Tropical African Spices as sources of reduced-risk pesticides. J Entomol. 2011;8 Suppl 1:16-26.

27. Pal LR. Effect of source and rate of nitrogen and phosphorus on yield nutrient uptake and apparent fertilizer nutrient recovery by maize in the Southern Guinea savanna. J Agr Sci Tech. 1991;1:21-4.

28. Adu-Dapaah HK, Cobbinah J, Asare EO. Effect of cocoa pod ash on the growth of maize. J Agric Sci. 1994;122:31-3.

29. Owolabi O, Adeleye A, Oladejo BT, Ojeniyi SO. Effect of wood ash on soil fertility and crop yield in Southwest Nigeria. Nigerian J Soil Sci. 2003;13:55-60.

30. Altieri AM. Agroecology, Small Farms, and Food Sovereignty. Monthly review / July-August. 2009;61:102-13.

31. ASWA-RUDEP (Association of south west agriculturist rural development project): A Baseline survey report of the south west region. Project for rural development and sustainable biodiversity conservation. In collaboration with the south west development authority (SOWEDA) and the ministry of agriculture and rural development; Buea, South west Region, Cameroon. 2008.

32. Abu GA, Djomo-Choumbou RF, Okpachu SA. Evaluating the constraints and opportunities of maize production in the west region of Cameroon for sustainable development. JSDA. 2011;13(No.4):189-96.

33. Sibuga KP: The role of women and children in weed management in smallholder farming systems. In Proceedings of the 17th East African Bi-annual Weed Science Conference: 27-29 September 1999; Harare, 1999: 85-90.

34. Labrada R, Caseley JC, Parker C. Preface. In: Labrada R, Caseley JC, Parker C, editors. Weed Management for Developing Countries. Rome: FAO; 1994.

35. Kekeunou S, Messi J, Weise S, Tindo M. Insect pests' incidence and variations due to forest landscape degradation in the humid forest zone of Southern Cameroon: farmers' perception and need for adopting an integrated pest management strategy. Afr J Biotechnol. 2006;5 Suppl 7:555-62.

36. Bosque-Perez NA. Major Insect pests of Maize in Africa: Biology and Control. IITA Research Guide 30. 2nd ed. Nigeria: Training Program; International Institute of Tropical Agriculture (IITA), Ibadan; 1995. p. 30.

37. Gurung AB. Insect - a mistake in god's creation? Tharu farmer's perspective and knowledge of insects: a case study of gobardiha village developpement committee, dangdeukhuri, Nepal. Agric Human Values. 2003:20:337-70

38. Ndemah R, Schulthess F, Korie S, Borgemeister C, Cardwell KF. Distribution, relative importance and effect of lepidopterous borers on maize yields in the forest zone and mid-altitude of Cameroon. J Econ Entomol. 2001;94:1434-44

39. Ngoko Z, Cardwell KF, Marasas WFO, Wingfield M, Ndemah R, Schulthess F Biological and physical constraints on maize production in the Humid Forest and Western Highlands of Cameroon. European Journal of Plant Pathology. 2002;108:893-902.

40. Aroga R. Méthods de lutte contre les foreurs de tiges et grains de maïs au Cameroon: EDITIONS ADG. Yaounde, Cameroon: ADG; 2007.

41. Poubom CFN, Awah ET, Tchuanyo M, Tengoua F. Farmer's perception of cassava and indigenous control methods in Cameroon. Int J Pest Manag. 2005;51 Suppl 2:157-64.

42. Pesticide Action Network (PAN). Les pesticides au Cameroun. Monitoring and Briefing. No. 7, June 2003. Africa: Pesticide Action Network; 2003. p. 44

43. Sonwa DJ, Coulibaly O, Weise SF, Akinwumi AA, Janssens MJJ. Management of cocoa: constraints during acquisition and application of pesticides in the humid forest zones of southern Cameroon. Crop Protection. 2008;27:1159-64.

44. Anon: Risks and consequences of the misuse of pesticides in the treatment of stored products. GASGA (Group for Assistance on Systems relating to Grains After harvest) and CTA, Wageningen. 1996; 20. No ISBN.

45. Boland J, Koomen I, de Jeude J v L, Oudejans J. Compounds, Use and Hazards. Wageningen: Agromisa foundation; 2004.

46. Matteson PC, Meltzer Ml, Knausenberger Wl: La privatisation de l'acquisition de la distribution et du marche' des pesticides en Afrique Sub- Saharienne. Agriculture et Developpement 1995, N02/95; 42-44.

47. Chiu) SZ(S-F). Laboratory of Insect Toxicology, South China Agricultural University, Guangzhou 51 0642, China. Entomologia Sinica. 1994; 1(No. 4):365-74.

\section{Submit your next manuscript to BioMed Central and take full advantage of:}

- Convenient online submission

- Thorough peer review

- No space constraints or color figure charges

- Immediate publication on acceptance

- Inclusion in PubMed, CAS, Scopus and Google Scholar

- Research which is freely available for redistribution

Submit your manuscript at www.biomedcentral.com/submit
C) Biomed Central 